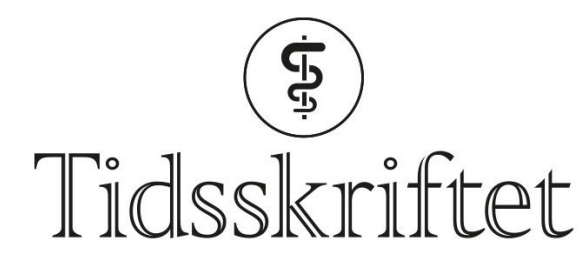

DEN NORSKE LEGEFORENING

\title{
Forside nr. 13/2019
}

FORSIDE

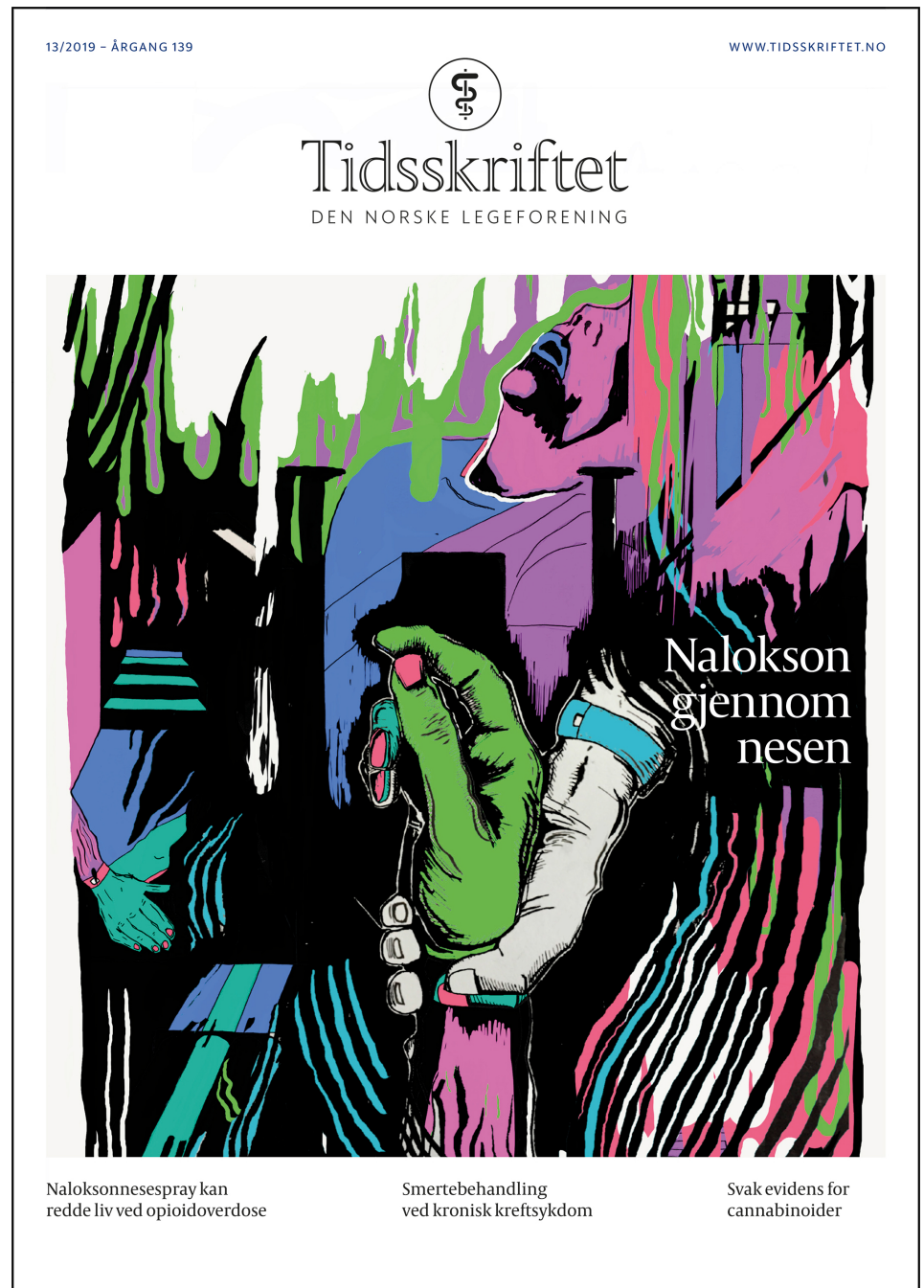

Illustrasjon (C) Cathrine Dahl og Ørjan Aas

Nalokson er livreddende motgift mot opioidoverdose. Den gis tradisjonelt av helsepersonell som intramuskulær eller intravenøs injeksjon, men nå har en norskutviklet nesespray med nalokson fått markedsføringstillatelse i tolv europeiske land. Dermed kan nalokson også være kameratredning. Nesesprayen deles nå ut til alle som kan komme til å bevitne en overdose. I dette nummeret av Tidsskriftet publiserer vi pilotstudien av nesesprayen.

Studien er viktig av flere grunner: Narkomane er en marginalisert gruppe som ofte overses. I denne studien er de imidlertid en ressurs; det er de som er tettest på overdosen når den skjer. Dermed er det de som har størst sjanse til å redde liv. Studien er også et eksempel på 
at det kan bli gode artikler av studentoppgaver, og at legemiddelutvikling er mulig også i små forskergrupper.

Forsideillustrasjonen til dette nummeret er det Cathrine Dahl og Ørjan Aas som står bak. Mer av deres arbeid finner du her: www.dahlaas.com

Publisert: 23. september 2019. Tidsskr Nor Legeforen. DOI: 10.4045/tidsskr.19.13.02

(C) Tidsskrift for Den norske legeforening 2020. Lastet ned fra tidsskriftet.no 